\title{
First Report of Macrocheles scutatiformis (Acari: Macrochelidae) Found on Insects and Soil beneath Animal Carcasses in Malaysia
}

(Laporan Pertama Penemuan Macrocheles scutatiformis (Acari: Macrochelidae) pada Serangga dan Tanah di Bahagian Bawah Badan Bangkai Haiwan di Malaysia)

\author{
AZIMA LAILI HANIFAH*, MARIANA AHAMAD, BAHARUdIN OMAR, AHMAD TAUFIK YUSOFF, \\ VISHALANI VISHNU NARAINASAMY \& GEN TAKAKU
}

\begin{abstract}
In a forensic acarology study, conducted in a secondary forest of Forensic Science Simulation Site, Universiti Kebangsaan Malaysia (UKM) in Bangi, Selangor, six carcasses consisted of three monkeys and three rabbits were placed individually in steel enclosures and observed for 35 days. The carcasses, the soil beneath them and pitfall traps were checked daily for insects and mites. A species of mesostigmatid mite, Macrocheles scutatiformis was discovered and this is a first time reported in Malaysia. There are about $94.0 \%$ of Macrocheles present inside the cages of the monkey and rabbit carcasses. Most mites in this study were collected from soil beneath the carcasses, on a dung beetle and a Chrysomya rufifacies larva. Our findings showed that M. scutatiformis have a potential role in forensic investigation involving dead animals perhaps corpses especially during the dry stage of decomposition.
\end{abstract}

Keywords: First report; insects; Macrocheles scutatiformis; Malaysia

ABSTRAK

Dalam kajian forensik akarologi yang dijalankan di hutan tropika sekunder di Tapak Simulasi Sains Forensik, Universiti Kebangsaan Malaysia (UKM) Bangi, Selangor, sebanyak enam bangkai haiwan terdiri daripada tiga monyet dan tiga arnab diletakkan secara individu di dalam sangkar dawai dan diperhatikan selama 35 hari. Pemeriksaan serangga dan tungau dilakukan setiap hari pada badan bangkai, tanah di bahagian bawah badan bangkai serta perangkap jatuhan. Spesies tungau Mesostigmata iaitu Macrocheles scutatiformis ditemui dan dilaporkan buat pertama kalinya di Malaysia. Sebanyak 94.0\% Macrocheles ditemui pada sangkar bangkai monyet dan arnab. Kebanyakan tungau ini dikutip pada tanah di bawah badan bangkai, pada kumbang dan juga pada larva Chrysomya rufifacies. Hasil kajian ini menunjukkan bahawa M. scutatiformis berpotensi dalam penyiasatan forensik melibatkan haiwan mati dan mungkin juga mayat manusia terutama ketika pereputan peringkat kering. Secara keseluruhan, hasil daripada kajian ini dapat membantu dalam penentuan selang masa pasca kematian, sekiranya spesies ini ditemui maka dapat disimpulkan bahawa bangkai atau mayat tersebut telah pun mencapai peringkat terakhir pereputan iaitu peringkat kering.

Kata kunci: Laporan pertama: Macrocheles scutatiformis; Malaysia; serangga

\section{INTRODUCTION}

Mite distribution studies have showed the presence of six species of Macrocheles in Malaysia namely Macrocheles kraepelini and Macrocheles hallidayi (Walter \& Krantz 1986), Macrocheles merdarius, M. muscaedomesticae, $M$. krantzi and M. subbadius were found on flies inhabiting poultry manure (Ho 1988). Currently there is no report of the genus Macrocheles on carcasses in Malaysia. Information on M. scutatiformis found on rabbit and monkey carrions in a secondary forest presented here provides further details of these carrion-frequenting mites. The present study is an attempt to determine the impact of different types of carcasses on the diversity of acari in a tropical secondary forest.

\section{MATERIALS AND METHODS}

\section{STUDY SITE AND EXPERIMENTAL DETAILS}

The study was conducted in a lowland secondary forest (42 $\mathrm{m}$ asl) at the Forensic Science Simulation Site of the Faculty of Health Sciences, Universiti Kebangsaan Malaysia, Bangi, Selangor $\left(2.90^{\circ} \mathrm{N}, 101.80^{\circ} \mathrm{E}\right)$. A total of six carcasses consisting of three monkeys, Macaca fasicularis (Raffles) and three New Zealand white rabbits, Oryctolagus cuniculus (Linnaeus) were individually placed in the middle of a steel cage $\left(0.61 \times 0.61 \times 0.61 \mathrm{~m}^{3}\right)$ and was observed for 35 days for the presence of arthropods. The rats and rabbits were obtained from the Animal House Facility, Faculty of Medicine, UKM while monkeys were 
provided by the Department of Wildlife and National Parks, Peninsular Malaysia (PERHILITAN). Prior to placement of carcasses, the animals were killed by fatal dose of intravenous injection of sodium pentobarbital (Dolethal). The killing procedure fulfilled the animal ethic guidelines as approved by the Animal Ethic Committee, Faculty of Medicine, UKM.

\section{ACARI SAMPLING}

Sampling of acari was performed daily at 10 am every morning for a period of 35 days starting from the day after placement of carcass in the study site. Sampling methods were as follows:

Two pitfall traps (Morill 1975) were set up at a distance 20 $\mathrm{cm}$ from the top and bottom of each carcass for collection of crawling arthropods. The traps which consist of a collecting bottle containing $70 \%$ ethanol was checked everyday for the presence of arthropods and the bottle with samples was then replaced. Soil samples were also taken from approximately $2 \mathrm{~cm}$ beneath each carcass daily using a spatula (Van Belle et al. 2009). The collected arthropods were identified at the Institute for Medical Research (IMR) in Kuala Lumpur. The samples were processed in the laboratory using heat escape method modified from the Berlese/Tullgren funnel (Southwood 1978).

\section{MOUNTING OF MESOSTIGMATID MITES}

Specimens were cleared in lactophenol for not less than 1 week at room temperature. For heavily sclerotized mites, the lateral margins were punctured to facilitate penetration of lactophenol. A drop of Hoyer's medium was placed on a glass slide prior to transferring of a mite from the lactophenol to the Hoyer's medium. The mite were pushed to the bottom of mounting medium and orientated so that it is ventral side up. A cover slip was placed over the medium and slides were kept in an incubator at $40^{\circ} \mathrm{C}$ for 1 week. The mounted specimens were identified using taxonomic keys (Krantz \& Walter 2009). Slides of identified mites were sent to Dr. Gen Takaku in the Biological Laboratory, Hokkaido, University of Education, Sapporo, Japan for confirmation of identification.

\section{RESULTS AND DISCUSSION}

The mites were recovered as early as on the third day of death till towards the end of the observation period. Most mites were collected after the first week of observation. This is in accordance with a similar study conducted in the rain forest of Oahu in Hawaii, USA (Goff 1991). The carcasses in Hawaii were showed to associate with more mites starting from day 11th of observation. There are all together three species of Macrocheles i.e. M. kraepelini, $M$. muscadomestica and M. scutatiformis. However the most recovered was the last species (Tables $1 \& 2$ ). Females of the species dominated the collections from both types of carcasses. The mites were mainly collected from soil beneath the carcasses. Similar finding has also been found by Anderson and Van Laerhoven (1996) that reported mites as the most abundant soil invertebrates beneath a corpse.

Four females M. scutatiformis mites were found attached on a dung beetle, Phaeochroops freenae and one female attached to the anterior part of a larva collected inside a pitfall trap near a rabbit carcass. Although there was carrion beetles belong to family Cleridae were collected, no mites were found on them. The finding is in contrary to other previous studies that reported Macrocheles mites of having intimate and specific association with carrion beetles (Perotti \& Braig 2009). The associations of Macrocheles with other arthropods may be useful in forensic investigations as an indicator of the time of arrival of their beetles or flies carrier. This is important as forensic investigations have so far been limited to insects, focusing mainly on flies and beetles as they are prominent in size and their presence at dead animal or human are more consistent.

In general, body of M. scutatiformis mite is oval in shape. The female have a slightly longer dorsal shield than the male. Sternal shield of female is sculptured with lines and punctuations and the ornamentation of the species is more developed than that of closely related species $M$. scutatus (Figure 1). The genital shield is flat with rounded front edge (Figure 2). In male, the genital shield is fused with the sternal shield (Figure 1). The sternogenital shield which elongated between coxae II and IV has five pairs of smooth setae. Ventrianal shield of female mite is with rounded sides and transverse lines (Figure 3). In the male however, the front edge and sides of the ventrianal shield is densely covered with small pits (Figure 3). Unlike the female, surface of the male's anal shield has a reticulate pattern instead of a distinct one. Chelicera of the mite consists of two digits, one is movable and another one is fixed. Fixed digit is dentate. Chelicera with spermatodactyl, i.e. sperm transfer organ is unique to the males and has been used as another important character to differentiate the sexes (Figure 4). Both sexes have a bristle brush and dense long pubescent bristles at the base of its chelicera. Besides the chelicera, leg II of the mite also plays a role in identifying the sexes. Legs II of a female is with thick bristles at the distal but with a large spine on the lower legs of the males (Figure 5). Similar spines are also present in legs IV of the males (Figure 5). The trochanter IV is with massive triangular spines and thick bristles at the distal (Figure 6).

It is interesting to note that only adults of the $M$. scutatiformis were recovered and the females represented most of them. Since most of the females were collected from soil, it is likely for them to be attracted to carcass for food (Doube et al. 1986; Weaver 2005) or possibly for place to lay eggs (Braig \& Perotti 2009). Other reasons are probably due to the butyric fermentation and advance decay of the carcasses that attract mites. Chelicerae of most female Macrocheles mites are adapted to hold on to the hairs of beetle or fly carriers for transportation (Perotti et al. 2010) and this may possibly be another reason for the discovery of more females than males. Moreover, the males of many 

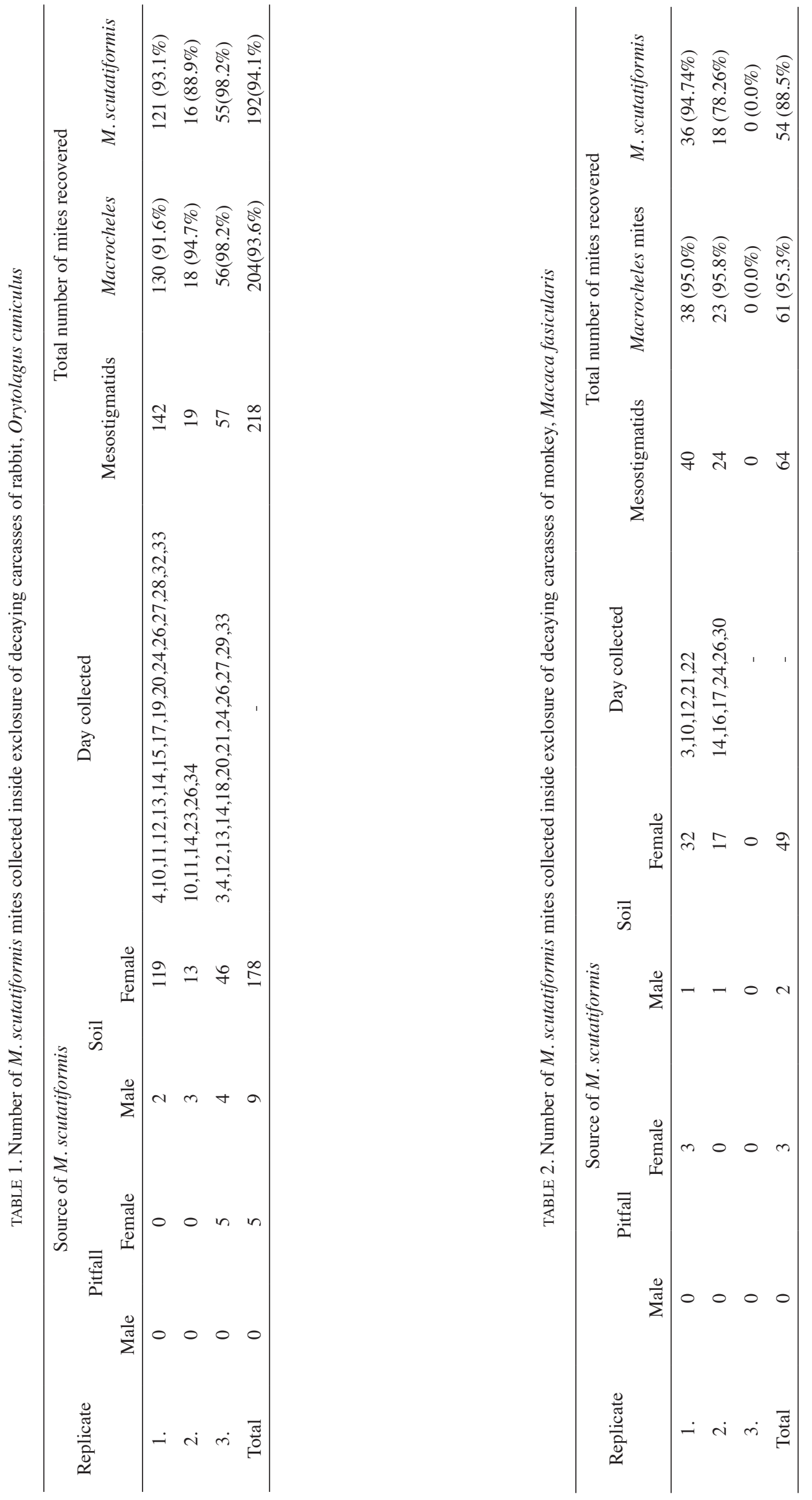


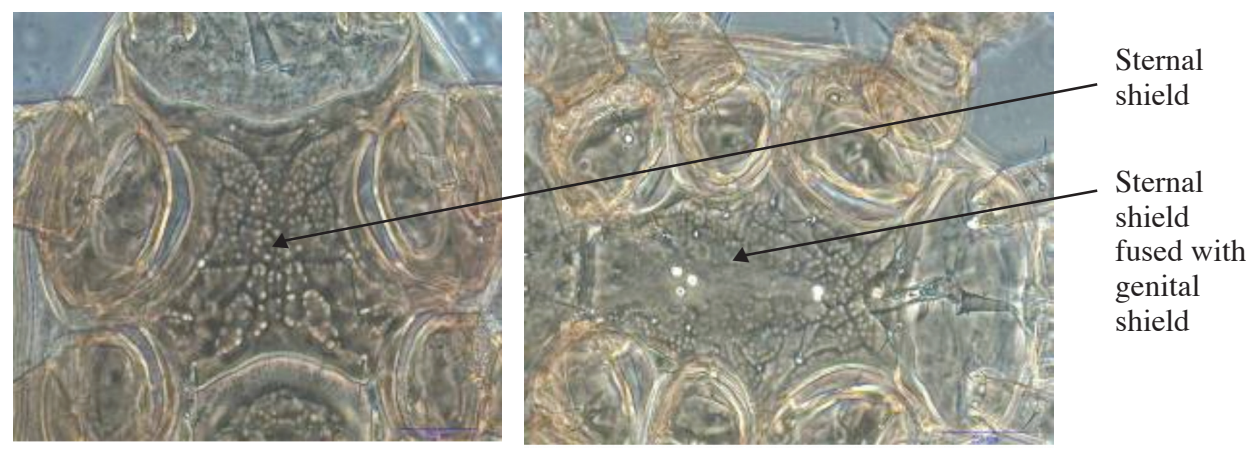

FIGURE 1. Sternal shield of female M. scutatiformis (left); sternal shield fused with genital shiled in male (right) (Scale: $225 \mu \mathrm{m}$ )

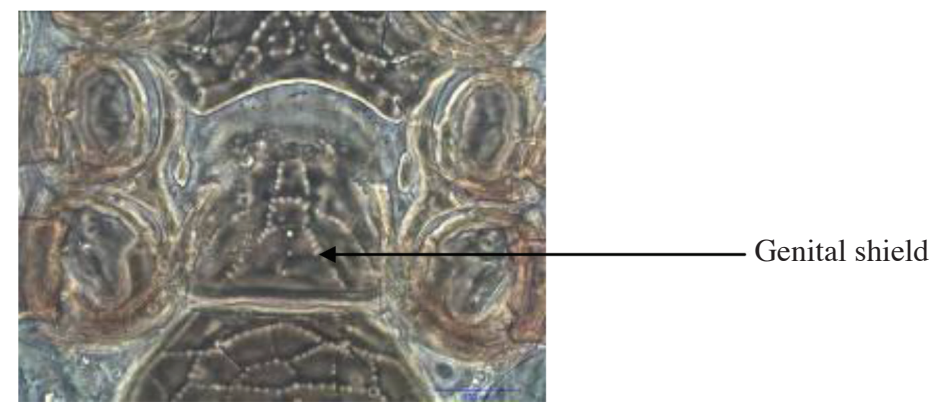

FIGURE 2. Genital shield of female (Scale: $225 \mu \mathrm{m}$ )

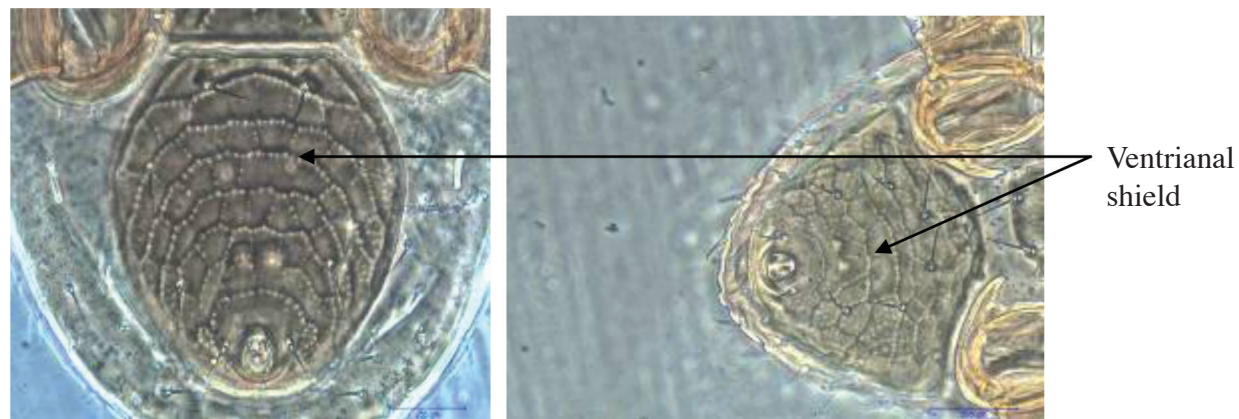

FIGURE 3. Ventrianal shields of female (left) and male (right) of M. scutatiformis (Ventral view). (Scale: $225 \mu \mathrm{m}$ )

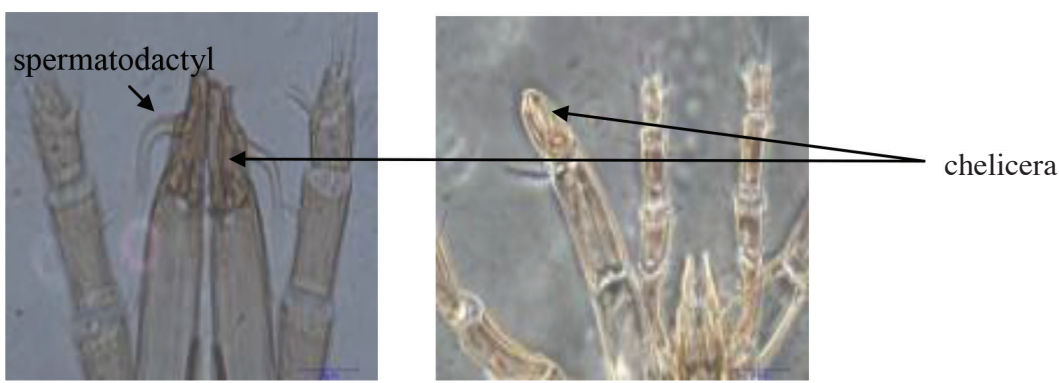

FIGURE 4. Chelicera of a male (left) and female (right) of M. scutatiformis. (Scale: $225 \mu \mathrm{m}$ ) 


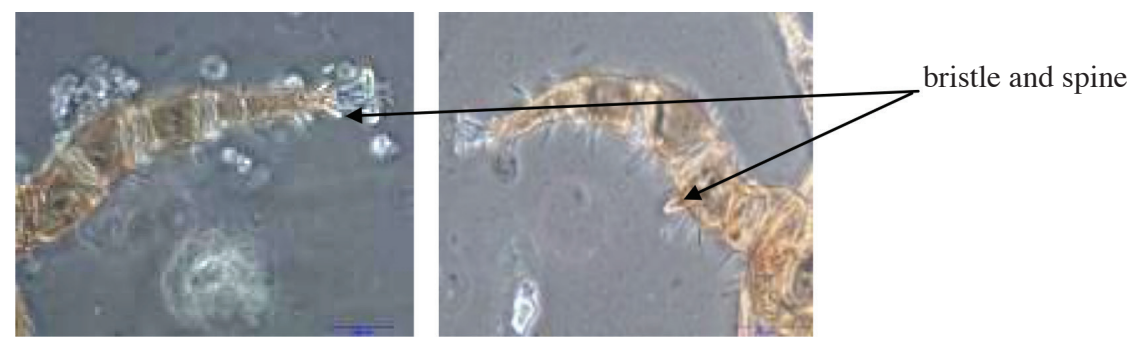

FIGURE 5. Bristle and spine at the distal of leg II of a female (left) and male (right) of M. scutatiformis. (Scale: $225 \mu \mathrm{m}$ )

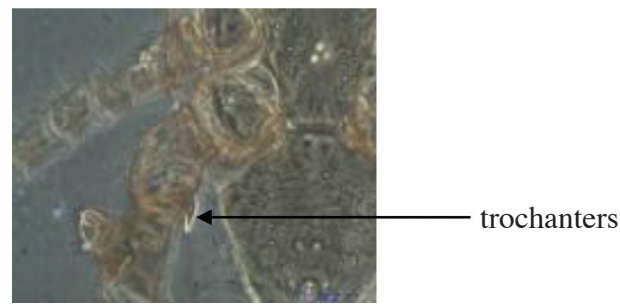

FIGURE 6. Trochanters of leg IV of M. scutatiformis. (Scale: $225 \mu \mathrm{m}$ )

phoretic mites were reported to be extremely rare (Perotti \& Braig 2009; Philips 1984). Eleven males collected in the present study were all from soil and thereby are not phoretics.

There are limitation and challenge faced throughout this study. The major challenge was on taxonomy and identification of the mites to species level. There was a serious lacking of taxonomic keys, pictorial keys and literature on Malaysian mites.

\section{CONCLUSION}

In most places, such as Canary Island, Spain (DomingoQuero et al. 2003; Moraza \& Pena 2005), Central and Southern Croatia (Kaczmarek \& Marquardt 2010; Kaczmarek et al. 2009), Dalmatia and Sourthern Turkmenia(Petrova 1967) this mite species is reported not to be associated with carcasses except in Malaysia (this paper). A further study on biology, behavior and ecology of the species is recommended to obtain information that might be useful in forensic science.

\section{ACKNOWLEDGEMENTS}

The authors wish to thank the Director-General of Health, Malaysia, for permission to publish this article. We would also like to thank Director General Department of Wildlife and National Parks, Peninsular Malaysia (PERHILITAN) for the permission to use monkeys in our research. We are grateful to staff of the Animal House Facility, Faculty of Medicine UKM for supplying the rats and rabbits. Animal use and procedure of the present study were approved by the Animal Ethic Committee, Faculty of Medicine, UKM (Approval number; FSK/BIOMED/2013/BAHARUDIN/25SEPT./538-OCT.-2013-MARCH-2015-CAT2-AR).

\section{REFERENCES}

Anderson, G.S. \& Van Laerhoven, S.L. 1996. Initial studies on insect succession on corpse in Southwestern British Columbia. Journal of the Forensic Science Society 41: 617-625.

Braig, H.K. \& Perotti, M.A. 2009. Carcasses and mites. Experimental and Applied Acarology 49:45-84.

Domingo-Quero, T., Alonso-Zarazaga, M.A., Sánchez-Ruiz, A., Araujo Armero, R., Navas Sánchez, A., Sánchez Moreno, S., García Becerra, R., Nebreda, M., Sánchez Ruiz, M., Fontal-Cazalla, F. \& Nieves-Aldrey, J.L. 2003. Inventariando La Biodiversidad en el Parque Nacional de la Caldera de Taburiente (La Palma, Islas Canarias, Espana): Novedades Cientificas (Inventorying biodiversity at National Park of La Caldera de Taburiente (La Palma, Canary Islands, Spain): scientific novelties. Graellsia 59: 45-68.

Doube, B.M., Macqueen, A. \& Huxham, K.A. 1986. Aspects of the predatory nature of Macrocheles peregrinus (Acarini: Acrochelidae) on two species of Haematobia fly (Diptera: Muscidae). Miscellaneous Publication of the Entomological Society of America 61: 132-141.

Goff, M.L. 1991. Comparison of insect species associated with decomposition remains recovered inside dwelling and outdoors on the island of Oahu, Hawaii. Journal of Forensic Science 36: 748-753.

Ho, T.M. 1988. Systematics of Macrochelidae (Acari: Mesostigmata) in central Peninsular Malaysia and the field and laboratory studies of Macrocheles muscaedomesticae (Scopoli) as a potential agent for biocontrol of Musca domestica $\mathrm{L}$. in poultry manure. $\mathrm{PhD}$ thesis, Universiti Sains Malaysia, Minden, Pulau Pinang (unpublished).

Kaczmarek, S., Marquardt, T. \& Falenczyk-Kozirog, K. 2009. Checklist of soil Mesostigmata (Acari) of Central Croatia (Dalmatia) with some microenvironmental remarks. Polish Journal of Entomology 78: 177-184.

Kaczmarek, S. \& Marquardt, T. 2010. Contribution to the diversity of soil mites (Acari, Gamasida) in southern Croatia (Dalmatia), with some ecological and zoogeographical notes. 
Biological Letter 47: 21-27. Available online at: http:/www. versita.com/science/lifesciences/bl/ DOI: 10.2478/v10120009-0016-y. Accessed on 23 Jan 2014.

Krantz, G.W. \& Walter, D.E. 2009. A Manual of Acarology. 3rd ed. Texas Tech University Press; Lubbock, Texas. p. 807. ISBN 978-0-89672-620-8

Moraza, M.L. \& Pena, M.A. 2005 . Acaros Mesostigmata (Acari, Mesostigmata) de Habitats Seleccionados de La Gomera (Islas Canarias, Espana) [Mesostigmatic mites (Acari, Mesostigmata) in selected habitats of La Gomera (Canary Islands, Spain)]. Graellsia 61: 109-114.

Morill, W.C. 1975. Plastic pitfall trap. Journal of Environmental Entomology 4: 596-597.

Perotti, M.A. \& Braig, H.R. 2009. Phoretic mites associated with animal and human decomposition. Experimental and Applied Acarology 49: 85-124.

Perotti, M.A., Braig, H.R. \& Lee Goff, M. 2010. Phoretic mites and carcasses: Acari transported by organisms associated with animal and human decomposition. In Current Concepts in Forensic Entomology, edited by Amendt, J., Campobasso, C.P., Lee Goff, M. \& Grassberger, M. Springer. ISBN 9781-4020-9683-9. pp. 69-92.

Petrova, A.D. 1967. New species of mites of the family Macrochelidae Vitzthum, 1930. Zoologicheskii Zhurnal. 46: 1037-1047.

Philips, J.R. 1984. Acarine symbionts of trogid beetles (Coleoptera: Trogidae). In VI International Congress of Acarology, edited by Griffiths, D.A., Bowman, C.E. Chichester: Ellis Horwood.

Southwood, T.R.E. 1978. Ecological Methods with Particular Reference to the Study of Insect Populations. London: Chapman and Hall.

Van Belle, L.E., David, O.C. \& Shari, L.F. 2009. Measurement of ninhydrin reactive nitrogen influx into gravesoil during aboveground abd belowground carcass (Sus domesticus) decomposition. Forensic Science International 193: 37-41.
Walter, D.E. \& Krantz, G.W. 1986. A review pf glaber group (s. str.) species of the genus Macrocheles (Acari: Macrochelidae) and a discussion of species complexes. Acarologia 27: 277 294.

Weaver, M. 2005. What happen to human body after we die? (www.madsci.org).

Azima Laili Hanifah, Mariana Ahamad, Ahmad Taufik Yussoff \& Vishalani Vishnu Narainasamy

Acarology Unit, Infectious Diseases Research Centre Institute for Medical Research, Jalan Pahang 50588 Kuala Lumpur

Malaysia

Baharudin Omar

Biomedical Department, Faculty of Health Science

Universiti Kebangsaan Malaysia

Jalan Raja Muda Abdul Aziz

50300 Kuala Lumpur

Malaysia

Gen Takaku

Biological Laboratory, Hokkaido

University of Education, Sapporo

Japan

*Corresponding author; email: azima@imr.gov.my

Received: 5 August 2014

Accepted: 22 January 2015 